\section{Effects of Seaweed Extract Application Rate and Method on Post-production Life of Petunia and Tomato Transplants}

\author{
Yuqi $\mathrm{Li}^{1,3}$ and Neil S. Mattson ${ }^{2}$
}

AdDitional INDEX wORDs. Ascophyllum nodosum, foliar spray, drench, drought stress, postharvest, shelf life, chlorophyll fluorescence

SUMMARY. Seaweed extracts are widely used as plant growth regulators in agriculture and horticulture for improvement of plant growth and development. This study investigated the effects of rockweed (Ascopbyllum nodosum) extract application method (foliar spray or substrate drench) and rate on growth and postharvest drought tolerance of petunia (Petunia bybrida) and tomato (Solanum lycopersicum) transplants grown in a commercial peat/perlite substrate. Foliar sprays significantly affected growth of petunia and tomato, but did not improve drought tolerance of petunia and tomato. Whereas, substrate drenches significantly improved drought tolerance of petunia and tomato compared with the control. Shoot fresh weight (FW), shoot dry weight (DW), root index (RI), and chlorophyll index (SPAD) of petunia and tomato increased significantly with increasing concentration of foliar spray rate up to $5 \mathrm{~mL} \cdot \mathrm{L}^{-1}$, but did not change significantly with further higher foliar spray rates. Weekly substrate drenches at $20 \mathrm{~mL} \cdot \mathrm{L}^{-1}$ significantly decreased $\mathrm{FW}, \mathrm{DW}, \mathrm{RI}$, and SPAD values of petunia and tomato. In this study, substrate drench at $5-10 \mathrm{~mL} \cdot \mathrm{L}^{-1}$ significantly increased flower number of petunia and tomato. The results of this study suggested that substrate drenches at $5-10 \mathrm{~mL} \cdot \mathrm{L}^{-1}$ are appropriate for the improvement of postharvest life of petunia and tomato transplants, and that foliar applications can increase plant growth.

S eaweed extracts and concentrates are used in agriculture and horticulture for its many beneficial effects on soil properties, plant growth, and crop yield (Blunden et al., 1996; Khan et al., 2009). More than 18 million tons of seaweed products are produced annually (Food and Agriculture Organization of the United Nations, 2011), a considerable portion of which is used as plant nutrient supplements or biostimulants to increase plant growth and yield (Borlongan et al., 2011; Craigie, 2011; Crouch and van Staden, 1992; Hurtado et al., 2009). Rockweed is one of the most widely researched and used seaweeds for the production of commercial extracts (Khan et al., 2009, 2011; Ugarte et al., 2006). Seaweed extracts are found to contain

We thank Dr. Holly A. Little for supplying rockweed extract and assistance in experimental design.

Use of trade names does not imply an endorsement of the products named or criticism of similar ones not named.

${ }^{1}$ School of Chemical Engineering and Food Science, Hubei University of Arts and Science, Xiangyang, Hubei Province 441053, China

${ }^{2}$ Department of Horticulture, Cornell University, 134A Plant Science Building, Ithaca, NY 14853

${ }^{3}$ Corresponding author. E-mail: yuqi.li@hotmail. com. plant growth substances such as cytokinins, auxin, indole acetic acid, and plant nutrients (Khan et al., 2009; MacKinnon et al., 2010; Rayorath et al., 2008a), but more recent studies indicate no biologically active levels of traditional plant growth regulators (Wally et al., 2013). There are beneficial effects of seaweed extract applications on plant early seed germination and establishment, improved crop performance and yield, increased resistance to biotic and abiotic stress, and enhanced postharvest shelf life of perishable products (Beckett and van Staden, 1989; Hankins and Hockey, 1990; Hurtado et al., 2012; Rayirath et al., 2009).

Petunia is one of the most popular bedding plants worldwide and the most popular bedding plant in the United States with an annual wholesale value of $\$ 130$ million (U.S. Department of Agriculture, 2014). Bedding plants are an important part of the urban public space and private gardens. However, they are not always properly watered and suffer from drought stress, especially when grown in containers (Chyliński et al., 2007). In response to inadequate water availability, wilting and flower drop commonly limit the postharvest and landscape longevity of ornamental plants. Therefore, drought tolerance is one of the most desirable traits for bedding plants ( $\mathrm{Hu}$ et al., 2012). Tomato is one of the most widely grown vegetables in the world (Passam, 2008 ). Tomato transplants in a retail setting also often suffer from inadequate watering. Increasing tomato drought tolerance is important for improving the establishment rate, its growth and yield. Therefore, many studies have been performed for improving tomato drought tolerance (Mishra et al., 2012; Ozenc, 2008; Sánchez-Rodríguez et al., 2012; Topcu et al., 2007). Rockweed extract [RWE (Stimplex $^{\circledR}$; Acadian Seaplants, Dartmouth, NS, Canada)] has been shown to increase the drought tolerance of container sweet orange (Citrus sinensis) plants (Spann and Little, 2011). However, to our knowledge, there is no report about the effect of seaweed extracts on the postharvest life of bedding plants and vegetable transplants.

Different plant species can have different responses to the application methods and rates of seaweed concentrate (Khan et al., 2009; Spann and Little, 2011). The objective of this study was to determine effects of RWE on plant growth and drought tolerance of tomato and petunia transplants when applied as a drench or foliar spray at various concentrations.

\section{Materials and methods}

PLANT MATERIALS AND EXPERIMENTAL DESIGN. 'Bravo White'

\begin{tabular}{llll}
\hline $\begin{array}{l}\text { Units } \\
\text { To convert U.S. to SI, } \\
\text { multiply by }\end{array}$ & U.S. unit & SI unit & $\begin{array}{l}\text { To convert SI to U.S., } \\
\text { multiply by }\end{array}$ \\
\hline 29.5735 & $\mathrm{fl} \mathrm{oz}$ & $\mathrm{mL}$ & 0.0338 \\
2.54 & Inch $(\mathrm{es})$ & $\mathrm{cm}$ & 0.3937 \\
25.4 & Inch $(\mathrm{es})$ & $\mathrm{mm}$ & 0.0394 \\
1 & $\mathrm{mmho} / \mathrm{cm}$ & $\mathrm{mS} \cdot \mathrm{cm}^{-1}$ & 1 \\
28.3495 & $\mathrm{oz}$ & $\mathrm{g}$ & 0.0353 \\
1 & $\mathrm{ppm}$ & $\mathrm{mg} \cdot \mathrm{L}^{-1}$ & 1 \\
0.001 & $\mathrm{ppm}$ & $\mathrm{mL} \cdot \mathrm{L}^{-1}$ & 1000 \\
0.9072 & Ton $(\mathrm{s})$ & $\mathrm{t}$ & 1.1023 \\
$\left({ }^{\circ} \mathrm{F}-32\right) \div 1.8$ & ${ }^{\circ} \mathrm{F}$ & ${ }^{\circ} \mathrm{C}$ & $\left({ }^{\circ} \mathrm{C} \times 1.8\right)+32$
\end{tabular}


petunia and 'Celebrity' tomato were used as plant materials. The experiment was conducted in a glasshouse at Cornell University in Ithaca, NY (lat. $42^{\circ} \mathrm{N}$ ) with a temperature set point of $19^{\circ} \mathrm{C}$. A $5 \times 2 \times 2$ factorial experiment (12 replicates per treatment) was designed with five RWE concentration levels, two RWE application methods, and two plants. Plug seedlings of petunia and tomato were obtained from a commercial producer. On 6 Oct. 2012, uniform 4-week-old seedlings of petunia and tomato were transplanted into 4-inch-diameter round pots $(495 \mathrm{~mL}$ volume) filled with a commercial peat/perlite substrate (LM-111; Lambert Peat Moss, Riviere-Ouelle, QC, Canada), and fertigated daily with $150 \mathrm{mg} \cdot \mathrm{L}^{-1}$ nitrogen $(\mathrm{N})$ from $21 \mathrm{~N}-2.2 \mathrm{P}-16.6 \mathrm{~K}$ fertilizer (Jack's Professional LX'M 21-5-20 All Purpose Water Soluble Fertilizer; J.R. Peters, Allentown, PA). 3 d after transplanting, petunia and tomato received weekly RWE treatments for 6 weeks, applied as either a foliar spray or substrate drench at concentrations of 0 , $2.5,5,10$, or $20 \mathrm{~mL} \cdot \mathrm{L}^{-1}$. The solutions were prepared with reverse osmosis water. The physicochemical properties of RWE used are as follows (w/w): cytokinins $0.01 \%, \mathrm{pH}$ 8.0, organic matter $8.0 \%$ to $12.0 \%$, $\mathrm{N} 0.1 \%$ to $0.6 \%$, phosphorus $\leq 0.04 \%$, potassium $\left(\mathrm{K}^{+}\right) 2.5 \%$ to $4.1 \%$, and ash (minerals) $8.0 \%$ to $12.0 \%$ (Stimplex $^{\circledR}$ crop biostimulant, Acadian Seaplants). The experimental unit was one plant in one pot. Foliar spray treatments were applied until the beginning of runoff. Substrate drench treatments were applied using $100 \mathrm{~mL}$ of solution per pot. After spray/drench applications, plants were not fertigated until the next day. The plants were grown under natural day lengths in late winter.

Data collection. At the end of 6-week growth period, six replicates per treatment were randomly sampled for measurement of substrate leachate $\mathrm{pH}$, electrical conductivity (EC) and nutrient concentrations, plant shoot FW, shoot DW, height, crown diameter, RI, number of open flowers (at anthesis), and leaf chlorophyll index of three recently mature leaves per plant (Minolta SPAD-502 chlorophyll meter; Spectrum Technologies, Plainfield, IL). Substrate leachate was collected by the pour-through extraction method (Wright, 1986). $\mathrm{pH}$ and EC meters were pHTestr 20 and ECTestr
11, respectively (Oakton Instruments, Vernon Hills, IL). Leachate elemental concentrations of calcium $\left(\mathrm{Ca}^{2+}\right)$, chloride $\left(\mathrm{Cl}^{-}\right), \mathrm{K}^{+}$, sodium $\left(\mathrm{Na}^{+}\right)$, ammonium-nitrogen $\left(\mathrm{NH}_{4}{ }^{+}-\mathrm{N}\right)$, and nitrate-nitrogen $\left(\mathrm{NO}_{3}{ }^{-} \mathrm{N}\right)$ were measured using a multi-ion meter (CG001; CleanGrow, Vacaville, CA). Plant height was measured as the distance from the medium surface to the tallest part of the plant. Crown diameter was recorded [(widest diameter + diameter perpendicular to widest diameter $) \div 2$ ] FW of plant shoots was measured and then oven dried at $70{ }^{\circ} \mathrm{C}$ for $48 \mathrm{~h}$ to determine DW. RI was evaluated using a 0 to 5 scale, with 0 indicating no visible roots at the substrate surfaces and 5 indicating visible roots were matted on the surface of the substrate (Bi et al., 2009).

The remaining six replicates per treatment were subjected to drought stress. Plants were well watered with tap water once $(0 \mathrm{~d})$ and brought to a postproduction life room (temperature $20{ }^{\circ} \mathrm{C}$, relative humidity $70 \%$, daylength $12 \mathrm{~h}$ under fluorescent lights providing about $5 \mu \mathrm{mol} \cdot \mathrm{m}^{-2} \cdot \mathrm{s}^{-1}$ photosynthetically active radiation). Leaf angles were measured with a digital protractor (Pro 360; Mitutoyo America, Aurora, IL) to quantify degree of leaf wilting. A leaf oriented completely horizontally (i.e., parallel to the bench surface below) was denoted $0^{\circ}$, whereas a leaf wilted and completely vertical was denoted as $90^{\circ}$. Leaf angles were measured at $0 \mathrm{~d}$ to determine base-line leaf angle $\left(A_{0}\right)$. Thereafter, daily measurements were taken. Three recently mature leaves per plant were measured and the average value was determined. Change in leaf angle $(A)$ was used as an indicator of wilt, which was calculated by the equation: $A=A_{0}-A_{n}$, where $A_{0}$ and $A_{n}$ represent leaf angle measurement at $0 \mathrm{~d}$ and $n \mathrm{~d}$, respectively.

Once plants in one treatment were fully wilted (leaves along the whole plant oriented vertically, but no necrosis on leaves and stems), pots in all treatments were rewatered with tap water. Leaf angle was monitored for $2 \mathrm{~d}$ after rewatering. Chlorophyll fluorescence, $F_{\mathrm{v}} / F_{\mathrm{m}}$ (the ratio of the variable fluorescence to the maximum fluorescence) was measured with a chlorophyll fluorescence analyzer (HandyPEA; Hansatech Instruments, King's Lynn, UK) $2 \mathrm{~d}$ after plants were rewatered. Before the measurements, the leaves were dark adapted for $30 \mathrm{~min}$ (clips with a 4-mm-diameter hole) at a temperature of $20^{\circ} \mathrm{C}$.

Statistical analysis. Analysis of variance on data were performed using the general linear model program of SAS (version 6.12; SAS Institute, Cary, NC). Means were separated using the least significance difference test at $P \leq 0.05$.

\section{Results}

Substrate leachate $\mathrm{pH}$, EC, AND ELEMENT CONCENTRATIONS. Substrate leachate $\mathrm{pH}$ and $\mathrm{EC}$ values of petunia were significantly affected by drench treatments $(P<0.05)$, but not foliar treatments (Table 1$). \mathrm{pH}$ and EC values increased significantly with increases in RWE drench application rates. Spray treatments did not significantly affect petunia substrate leachate nutrient concentration except for $\mathrm{NH}_{4}{ }^{+}-\mathrm{N}$. $\mathrm{Ca}^{2+}$ concentration decreased from 77.9 to $5.3 \mathrm{mg} \cdot \mathrm{L}^{-1}$ as RWE drench rate increased from 0 to $20 \mathrm{~mL} \cdot \mathrm{L}^{-1}$. However, $\mathrm{K}^{+}$and $\mathrm{Cl}^{-}$ concentrations in leachate increased significantly with increase in RWE drench rate $(P<0.05)$. Substrate leachate $\mathrm{Na}^{+}$and $\mathrm{NO}_{3}{ }^{-}-\mathrm{N}$ concentrations had similar changes, which increased with increases in RWE drench rate up to $10 \mathrm{~mL} \cdot \mathrm{L}^{-1}$, but did not increase with a further increase in drench rate to $20 \mathrm{~mL} \cdot \mathrm{L}^{-1} \mathrm{RWE}$. Similar trends were found for substrate leachate $\mathrm{pH}, \mathrm{EC}$, and element concentrations of tomato (data not shown).

EFFECT OF RWE ON THE GROWTH AND FLOWERING OF PETUNIA AND TOMATO. In response to RWE foliar application, petunia exhibited an increase in FW, DW, and RI as RWE application increased from 0 to $5 \mathrm{~mL} \cdot \mathrm{L}^{-1}$ but did not further increase as greater concentrations of RWE were applied (Table 2). Petunia shoot FW and DW increased by $16 \%$ and $14 \%$, respectively, as RWE foliar application increased from 0 to $5 \mathrm{~mL} \cdot \mathrm{L}^{-1}$. The SPAD chlorophyll index exhibited a similar trend but with no further increases in SPAD above $2.5 \mathrm{~mL} \cdot \mathrm{L}^{-1}$ RWE. In contrast to foliar sprays, growth attributes of petunia (FW, DW, $\mathrm{RI}$, and SPAD) decreased significantly $(P<0.05)$ with increase in substrate drench rate. Petunia DW decreased from 3.07 to $2.48 \mathrm{~g}$ as drench application rate increased from 0 to $20 \mathrm{~mL} \cdot \mathrm{L}^{-1}$. Petunia flower number was unaffected significantly by RWE spraying 
Table 1. Effect of rockweed extract (RWE) application rate and method on substrate leachate pH, electrical conductivity (EC) and nutrient concentration for petunia. Beginning from $3 \mathrm{~d}$ after transplanting, petunia received weekly RWE treatments for 6 weeks, applied as either a foliar spray or substrate drench at concentrations of $0,2.5,5,10$, or $20 \mathrm{~mL} \cdot \mathrm{L}^{-1}$. The solutions were prepared with reverse osmosis water. Data were determined through pour-through measurements taken 6 weeks after RWE treatments.

\begin{tabular}{|c|c|c|c|c|c|c|c|c|}
\hline \multirow{2}{*}{$\begin{array}{l}\text { Treatment } \\
\left(\mathrm{mL} \cdot \mathrm{L}^{-1}\right)^{\mathrm{z}}\end{array}$} & \multirow[b]{2}{*}{$\mathrm{pH}$} & \multirow{2}{*}{$\begin{array}{c}\mathrm{EC} \\
\left(\mathrm{mS} \cdot \mathrm{cm}^{-1}\right)^{\mathrm{z}}\end{array}$} & \multicolumn{6}{|c|}{ Substrate leachate nutrient concn $\left(\mathrm{mg} \cdot \mathrm{L}^{-1}\right)^{\mathrm{z}}$} \\
\hline & & & Calcium & Potassium & Sodium & $\mathrm{NH}_{4}{ }^{+}-\mathrm{N}^{\mathrm{y}}$ & $\mathrm{NO}_{3}{ }^{-}-\mathbf{N}^{\mathrm{y}}$ & Chloride \\
\hline \multicolumn{9}{|l|}{ Spray } \\
\hline 2.5 & $6.03 \mathrm{ab}$ & $2.80 \mathrm{a}$ & $117.8 \mathrm{a}$ & $15.1 \mathrm{a}$ & $78.8 \mathrm{a}$ & $3.61 \mathrm{bc}$ & $12.4 \mathrm{a}$ & $28.9 \mathrm{a}$ \\
\hline 5.0 & $6.08 \mathrm{ab}$ & $2.70 \mathrm{a}$ & $117.5 \mathrm{a}$ & $17.8 \mathrm{a}$ & $79.5 \mathrm{a}$ & $2.94 \mathrm{c}$ & $13.0 \mathrm{a}$ & $22.0 \mathrm{a}$ \\
\hline 10.0 & $5.91 \mathrm{~b}$ & $2.76 \mathrm{a}$ & $105.6 \mathrm{a}$ & $22.1 \mathrm{a}$ & $69.8 \mathrm{a}$ & $4.40 \mathrm{bc}$ & $11.0 \mathrm{a}$ & $25.6 \mathrm{a}$ \\
\hline \multicolumn{9}{|l|}{ Drench } \\
\hline 0.0 & $6.06 \mathrm{c}$ & $1.46 \mathrm{c}$ & $77.9 \mathrm{a}$ & $10.7 \mathrm{~d}$ & $19.0 \mathrm{c}$ & $2.83 \mathrm{ab}$ & $11.4 \mathrm{c}$ & $9.9 \mathrm{~d}$ \\
\hline 2.5 & $6.10 \mathrm{c}$ & $1.50 \mathrm{c}$ & $61.3 \mathrm{~b}$ & $19.5 \mathrm{~d}$ & $28.2 \mathrm{bc}$ & $1.60 \mathrm{bc}$ & $26.6 \mathrm{~b}$ & $30.3 \mathrm{c}$ \\
\hline 5.0 & $6.17 \mathrm{c}$ & $1.64 \mathrm{bc}$ & $48.5 \mathrm{c}$ & $72.3 \mathrm{c}$ & $41.2 \mathrm{~b}$ & $1.26 \mathrm{c}$ & $30.5 \mathrm{ab}$ & $43.0 \mathrm{bc}$ \\
\hline
\end{tabular}

${ }^{\mathrm{z}} 1 \mathrm{~mL} \cdot \mathrm{L}^{-1}=1000 \mathrm{ppm}, \mathrm{lmS} \cdot \mathrm{cm}^{-1}=1 \mathrm{mmho} / \mathrm{cm}, 1 \mathrm{mg} \cdot \mathrm{L}^{-1}=1 \mathrm{ppm}$.

${ }^{y} \mathrm{NH}_{4}{ }^{+} \mathrm{N}=$ ammonium-nitrogen; $\mathrm{NO}_{3}{ }^{-}-\mathrm{N}=$ nitrate-nitrogen.

${ }^{x}$ Means $(n=6)$ in each column followed by the same letters are not significantly different for foliar spray and substrate drench treatments, respectively, according to least significant difference test at $P>0.05$.

wProbability values were obtained using the general linear model procedure of SAS (version 6.12) for significant effect of RWE application rates under foliar spray and substrate drench treatments, respectively; ${ }^{\mathrm{Ns}}$ nonsignificant at $P>0.05$.

treatment. On the contrary, substrate drenches at $5-10 \mathrm{~mL} \cdot \mathrm{L}^{-1}$ increased significantly flower number compared with the control $(P<$ $0.05)$. Petunia with $5 \mathrm{~mL} \cdot \mathrm{L}^{-1} \mathrm{RWE}$ had 8.5 flowers per plant vs. 5.5 for the control treatment.

Tomato FW increased significantly with increasing RWE spray rate (Table 2). The opposite trend was found for substrate drenches. Compared with the control, $20 \mathrm{~mL} \cdot \mathrm{L}^{-1}$ of RWE spray treatment significantly increased tomato DW, RI, and the number of flowers. As RWE drench treatment concentration increased from 0 to 20 $\mathrm{mL} \cdot \mathrm{L}^{-1}$ tomato plant $\mathrm{FW}, \mathrm{DW}$, and SPAD significantly decreased. The 10 $\mathrm{mL} \cdot \mathrm{L}^{-1}$ of RWE drench treatment increased the number of tomato flowers compared with the control $(P<0.05)$.

EFFECT OF RWE ON DROUGHT TOLERANCE OF PETUNIA AND TOMATO. The change in leaf angle during the postharvest period reflects a quantification of plant wilting response to drought stress and subsequent recovery following rewatering. RWE foliar spray treatment did not significantly affect the change in petunia leaf angle. However, substrate drenches significantly decreased the change in petunia leaf angle compared with the control beginning after $5 \mathrm{~d}$ of drought stress and continuing until
$10 \mathrm{~d}$ when the plants were rewatered (Fig. 1), indicating decreased wilting. The delay in wilting response was increased with increasing concentration of RWE. Further, petunias under the $5-20 \mathrm{~mL} \cdot \mathrm{L}^{-1}$ of substrate drench treatments recovered best after rewatering.

RWE spray and drench treatments significantly affected the change in tomato leaf angle measurement beginning after $3 \mathrm{~d}$ of drought stress. RWE spray at $20 \mathrm{~mL} \cdot \mathrm{L}^{-1}$ increased the change in tomato leaf angle, indicating that RWE spraying treatment reduced tomato drought tolerance, under this treatment. There were no significant differences in tomato leaf angle under other foliar spray rates. Drenches decreased the change in tomato leaf angle, indicating that drench treatments increased tomato drought tolerance. The effect was similar with petunia whereby increasing RWE drench concentration led to greater drought resistance. After rewatering, all tomato plants recovered well and there was not a significant RWE response.

Drench treatments, especially 5 $\mathrm{mL} \cdot \mathrm{L}^{-1}$ and greater concentrations of RWE significantly increased petunia $F_{\mathrm{v}} / F_{\mathrm{m}}$ compared with the control. Foliar spray did not significantly affect petunia $F_{\mathrm{v}} / F_{\mathrm{m}}$ (Fig. 2 ). Tomato $F_{\mathrm{v}} / F_{\mathrm{m}}$ was unaffected by RWE spray or drench treatments.

\section{Discussion and conclusions}

Rockweed concentrate is reported to contain various components such as macro and micro nutrients, amino acids, vitamins, cytokinins, auxins, and abscisic acid-like growth substances, which affect the properties of growing media, plant growth, and crop yield (Craigie, 2011; Khan et al., 2009; Rayirath et al., 2009; Zhang and Ervin, 2004). In this study, drenches significantly affected substrate $\mathrm{pH}$ and EC and several measured elements. RWE drench increased substrate $\mathrm{Na}^{+}, \mathrm{K}^{+}$, $\mathrm{Cl}^{-}$, and $\mathrm{NO}_{3}{ }^{-}-\mathrm{N}$. The opposite trends were found for $\mathrm{Ca}^{2+}$ concentrations. These changes could possibly be attributed to a variety of constituents within the aqueous alkaline extract of rockweed, including elemental constituents, secondary compounds that may contain these elements (Khan et al., 2009; Wally et al., 2013), and effects on plant nutrient uptake and substrate retention of nutrients (Spann and Little, 2011; Wally et al., 2013).

Different plant species can have different responses to the application methods and rates of seaweed concentrates. Root growth of tomato was 
Table 2. Effect of rockweed extract (RWE) application rate and method on the growth and flowering of petunia and tomato. Beginning from $3 \mathrm{~d}$ after transplanting, petunia and tomato received weekly RWE treatments for 6 weeks, applied as either a foliar spray or substrate drench at concentrations of $0,2.5,5,10$, or $20 \mathrm{~mL} \cdot \mathrm{L}^{-1}$. The solutions were prepared with reverse osmosis water. Data were collected 6 weeks after RWE treatments.

\begin{tabular}{|c|c|c|c|c|c|c|c|c|c|c|}
\hline \multirow[b]{2}{*}{$\begin{array}{l}\text { Treatment } \\
\left(\mathrm{mL} \cdot \mathrm{L}^{-1}\right)^{\mathrm{z}}\end{array}$} & \multicolumn{5}{|c|}{ Petunia $^{y}$} & \multicolumn{5}{|c|}{ Tomato } \\
\hline & $\begin{array}{c}\text { FW } \\
{\text { (g/plant })^{z}}^{\text {g }}\end{array}$ & $\begin{array}{c}\text { DW } \\
\text { (g/plant) }\end{array}$ & $\begin{array}{c}\mathrm{RI} \\
(0-5 \text { scale })\end{array}$ & $\begin{array}{c}\text { Flowers } \\
\text { (no./plant) }\end{array}$ & SPAD & $\begin{array}{c}\text { FW } \\
\text { (g/plant) }\end{array}$ & $\begin{array}{c}\text { DW } \\
\text { (g/plant) }\end{array}$ & $\begin{array}{c}\mathrm{RI} \\
(0-5 \text { scale })\end{array}$ & $\begin{array}{c}\text { Flowers } \\
\text { (no./plant) }\end{array}$ & SPAD \\
\hline \multicolumn{11}{|l|}{ Spray } \\
\hline 0.0 & $33.4 b^{x}$ & $2.77 \mathrm{~b}$ & $2.9 \mathrm{c}$ & $2.1 \mathrm{a}$ & $45.0 \mathrm{~b}$ & $69.6 \mathrm{~b}$ & $10.1 \mathrm{~b}$ & $3.1 \mathrm{c}$ & $5.2 \mathrm{~b}$ & $39.5 \mathrm{a}$ \\
\hline 2.5 & $36.9 \mathrm{ab}$ & $2.90 \mathrm{~b}$ & $3.8 \mathrm{~b}$ & $2.9 \mathrm{a}$ & $48.8 \mathrm{a}$ & $70.4 \mathrm{~b}$ & $10.3 \mathrm{ab}$ & $3.2 \mathrm{c}$ & $4.8 \mathrm{~b}$ & $39.3 \mathrm{a}$ \\
\hline 5.0 & $38.9 \mathrm{a}$ & $3.17 \mathrm{ab}$ & $4.6 \mathrm{a}$ & $3.4 \mathrm{a}$ & $49.6 \mathrm{a}$ & $72.6 \mathrm{~b}$ & $10.4 \mathrm{ab}$ & $3.4 \mathrm{bc}$ & $4.5 \mathrm{~b}$ & $40.0 \mathrm{a}$ \\
\hline Significance ${ }^{w}$ & 0.0210 & 0.0140 & 0.0013 & NS & 0.0007 & $<0.0001$ & NS & 0.0005 & $<0.0001$ & ns \\
\hline \multicolumn{11}{|l|}{ Drench } \\
\hline 0.0 & $32.9 \mathrm{a}$ & $3.07 \mathrm{a}$ & $3.9 \mathrm{a}$ & $5.5 \mathrm{c}$ & $50.7 \mathrm{a}$ & $71.9 \mathrm{a}$ & $10.4 \mathrm{a}$ & $3.9 \mathrm{a}$ & $8.0 \mathrm{~b}$ & $40.4 \mathrm{a}$ \\
\hline 2.5 & $30.6 \mathrm{a}$ & $2.96 \mathrm{a}$ & $3.1 \mathrm{~b}$ & $6.5 \mathrm{bc}$ & $45.3 \mathrm{~b}$ & $70.3 \mathrm{a}$ & $10.1 \mathrm{a}$ & $4.2 \mathrm{a}$ & $8.5 \mathrm{~b}$ & $39.5 \mathrm{ab}$ \\
\hline 5.0 & $29.1 \mathrm{a}$ & $2.85 \mathrm{ab}$ & $2.9 \mathrm{~b}$ & $8.5 \mathrm{a}$ & $41.8 \mathrm{~b}$ & $65.5 \mathrm{ab}$ & $9.4 \mathrm{a}$ & $4.0 \mathrm{a}$ & $8.5 \mathrm{~b}$ & $38.6 \mathrm{ab}$ \\
\hline
\end{tabular}

${ }^{2} 1 \mathrm{~mL} \cdot \mathrm{L}^{-1}=1000 \mathrm{ppm}, \mathrm{lg}=0.0353 \mathrm{oz}$.

${ }^{\mathrm{y}} \mathrm{FW}=$ shoot fresh weight; $\mathrm{DW}=$ shoot dry weight; $\mathrm{RI}=$ root index with $0=$ no visible roots at the substrate surfaces and $5=$ visible roots were matted on the surface of the substrate, SPAD = leaf chlorophyll index measured using a chlorophyll meter (Minolta SPAD-502).

${ }^{x}$ Means $(n=6)$ in each column followed by the same letters are not significantly different for foliar spray and substrate drench treatments, respectively, according to least significant difference test at $P>0.05$.

"Probability values were obtained using the general linear model procedure of SAS (version 6.12) for significant effect of RWE application rates under foliar spray and substrate drench treatments, respectively; ${ }^{\mathrm{N}}$ nonsignificant at $P>0.05$.

inhibited at high concentrations ( $1: 100$ seaweed extract:water) but stimulatory effects were found at lower concentrations (1:600), irrespective of root applications and foliar sprays (Finnie and van Staden, 1985). Atzmon and van Staden (1994) found that foliar application can increase the total plant weight of stone pine (Pinus pinea), but root drenches did not change the total plant weight. Application to the soil of an aqueous alkaline extract of rockweed resulted in higher concentrations of chlorophyll in the leaves of treated plants [tomato, dwarf french bean (Phaseolus vulgaris), wheat (Triticum aestivum), barley (Hordeum vulgare), and maize (Zea mays)] than those of untreated controls (Blunden et al., 1996; Khan et al., 2009). When the seaweed extract was applied as a foliar spray, similar effects on leaf chlorophyll contents were obtained for tomato, wheat, barley, and maize except in the case of dwarf french bean plants (Blunden et al., 1996; Whapham et al., 1993). In this study, RWE spray and drench treatments did not significantly affect the height and crown diameter of petunia or tomato (data not shown). Petunia FW, DW, RI, and SPAD increased significantly with increasing RWE foliar spraying rate up to $5 \mathrm{~mL} \cdot \mathrm{L}^{-1}$, but did not change with further increase in spraying rate. This increase in SPAD may be due to betaines in the seaweed extract increasing chlorophyll levels in the plant (Whapham et al., 1993). On the contrary, weekly substrate drenches at $20 \mathrm{~mL} \cdot \mathrm{L}^{-1} \mathrm{sig}$ nificantly decreased FW, DW, RI, and SPAD values of petunia and tomato. This decrease in growth may have been related to high substrate $\mathrm{pH}$, resulting in decrease in substrate $\mathrm{Ca}^{2+}$ concentrations, rather than an inhibitory effect of the RWE. In addition, drench treatment could cause an osmotic stress to petunia and tomato transplants due to increase in substrate $\mathrm{Na}^{+}$and $\mathrm{Cl}^{-}$concentrations, resulting in the reduction in $\mathrm{FW} /$ DW (Tables 1 and 2). Seaweed concentrates have been reported to trigger early flowering of crop plants. For example, tomato seedlings treated with seaweed concentrate set more flowers earlier than the control plants (Crouch and van Staden, 1992). In our experiment, foliar sprays did not affect petunia flowering, but $5-10 \mathrm{~mL} \cdot \mathrm{L}^{-1}$ of RWE substrate drenches significantly increased petunia flower number. These results indicate that $5-10 \mathrm{~mL} \cdot \mathrm{L}^{-1}$ of RWE drench treatment is appropriate for enhancing flowering of petunia. Similar trends were found for tomato growth and flowering.

More recent studies indicate that seaweed extracts can stimulate increases in endogenous phytohormones such as cytokinins, auxin, indole acetic acid, and gibberellic acid, which can improve growth and development, as well as protect plants from various stresses such as drought, salinity, and temperature (Khan et al., 2009, 2011; Rayorath et al., 2008b; Wally et al., 2013). In this study, RWE foliar sprays were not effective for the improvement of the drought tolerance of petunia and tomato, which differed from previous studies (Spann and Little, 2011). On the contrary, substrate drenches especially $>5 \mathrm{~mL} \cdot \mathrm{L}^{-1}$ significantly improved drought resistance of petunia and tomato. The $F_{\mathrm{v}} / F_{\mathrm{m}}$ ratio is an index of the maximum photochemical efficiency of photosystem II complex in the dark-adapted state and a decrease in this parameter is a reliable sign of photoinhibition (Gong et al., 2013). The $F_{\mathrm{v}} / F_{\mathrm{m}}$ ratio can also be used as a reliable indicator of drought stress (Krause, 1988). In this study, plants that received substrate drenches especially $>5 \mathrm{~mL} \cdot \mathrm{L}^{-1}$ exhibited a significant 

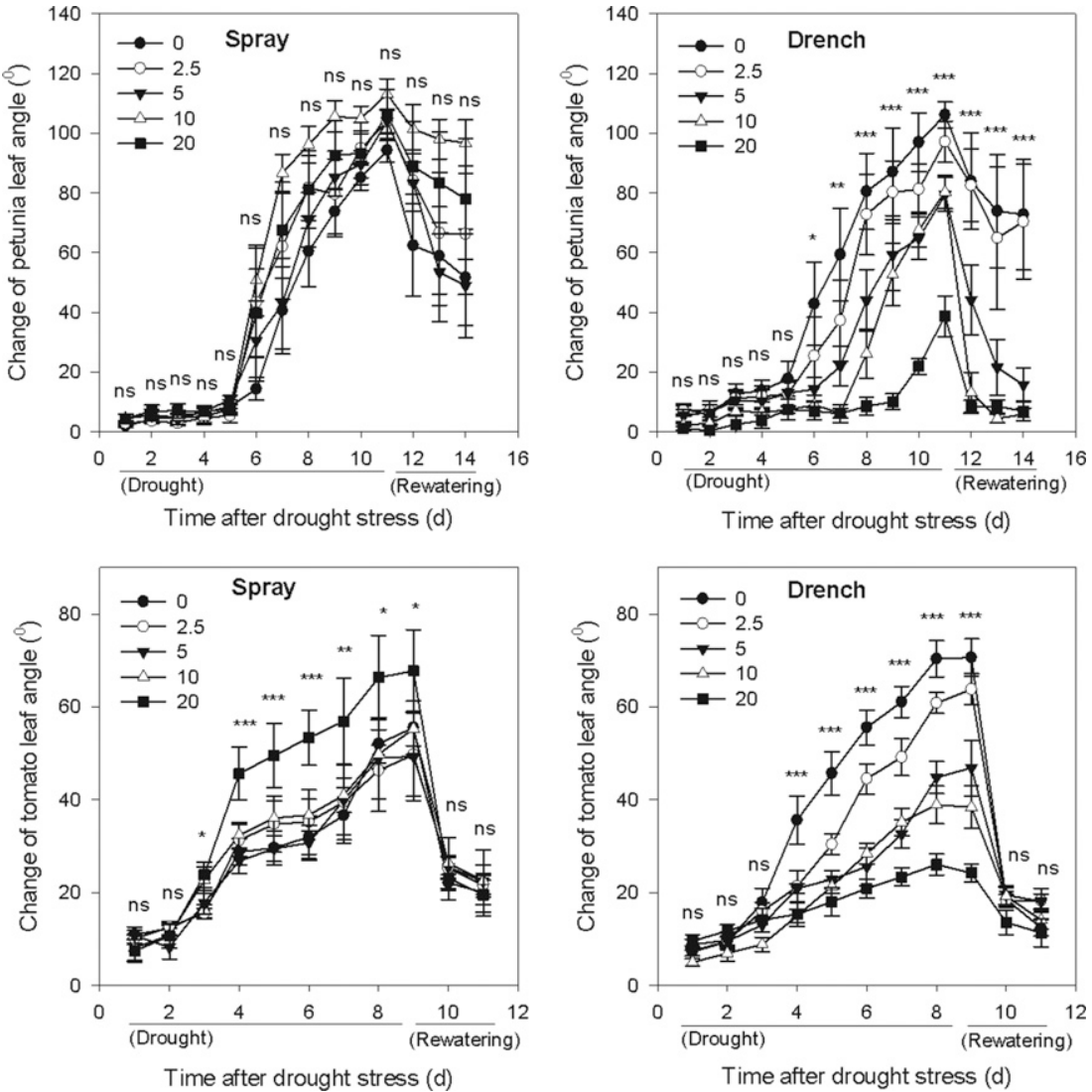

Fig. 1. Effect of rockweed extract application rate and method on the changes in petunia and tomato leaf angle during drought stress and rewatering. Drought stress was performed after petunia and tomato received weekly foliar spray or substrate drench treatments for 6 weeks. Once plants in one treatment were fully wilted (leaves along the whole plant oriented vertically, but no necrosis on leaves and stems), pots in all treatments were rewatered with tap water. Statistical analyses were performed using the general linear model procedure of SAS (version 6.12). The vertical bars represent the standard error $(n=6)$; ${ }^{\text {Ns }}$ nonsignificant at $P>0.05,{ }^{*} P<$ $0.05,{ }^{*} P<0.01, * * * P<0.001$.
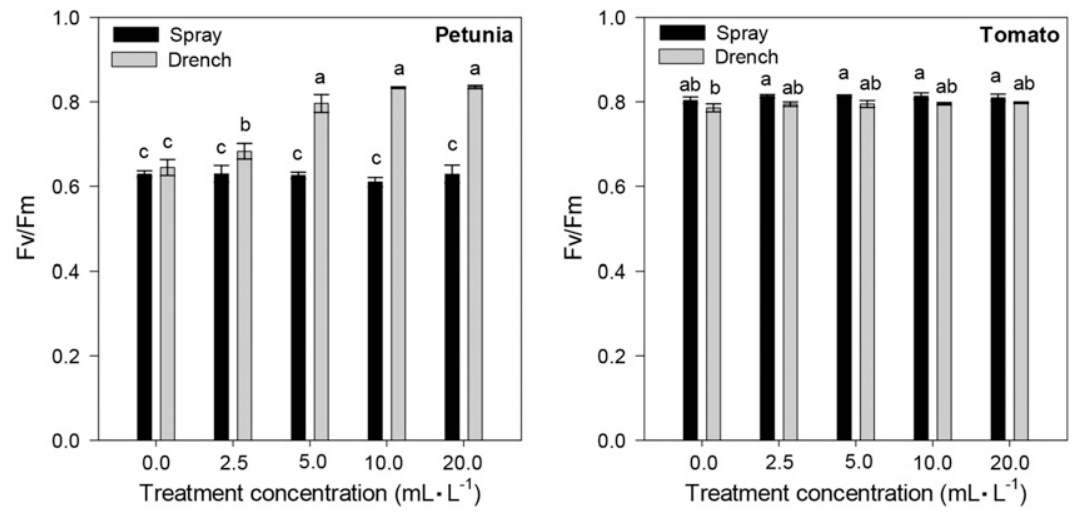

Fig. 2. Effect of rockweed extract application rate and method on petunia and tomato leaf chlorophyll fluorescence $\left(F_{\mathrm{v}} / F_{\mathrm{m}}\right) . F_{\mathrm{v}} / F_{\mathrm{m}}$, the ratio of the variable fluorescence to the maximum fluorescence, was measured with a chlorophyll fluorescence analyzer (Handy-PEA) $2 \mathrm{~d}$ after plants were rewatered. Before the measurements, the leaves were dark adapted for $30 \mathrm{~min}$ (clips with a 4 -mm-diameter hole) at a temperature of $20^{\circ} \mathrm{C}$. Different letters indicate significant differences according to least significant difference test at $P<0.05$. The bars represent the standard error $(\mathrm{n}=6) ; 1 \mathrm{~mL} \cdot \mathrm{L}^{-1}=1000 \mathrm{ppm}$. increase in $F_{\mathrm{v}} / F_{\mathrm{m}}$ compared with the control plants as measured at $2 \mathrm{~d}$, indicating that RWE led to an increase in photochemical efficiency after drought stress.

In conclusion, the results of this study suggested that RWE substrate drenches at $5-10 \mathrm{~mL} \cdot \mathrm{L}^{-1}$ are appropriate for the improvement of postharvest life of petunia and tomato transplants, however monitoring of substrate $\mathrm{pH}$ should be done. Additionally, RWE foliar sprays were shown to be appropriate for improving growth of petunia and tomato.

\section{Literature cited}

Atzmon, N. and J. van Staden. 1994. The effect of seaweed concentrates on the growth of Pinus pinea seedlings. New For. 8:279-288.

Beckett, R.P. and J. van Staden. 1989. The effect of seaweed concentrate on the growth and yield of potassium stressed wheat. Plant Soil 116:29-36.

Bi, G., W.B. Evans, and G.B. Fain. 2009. Use of pulp mill ash as a substrate component for greenhouse production of marigold. HortScience 44:183-187.

Blunden, G., T. Jenkins, and Y.W. Liu. 1996. Enhanced leaf chlorophyll levels in plants treated with seaweed extract. J. Appl. Phycol. 8:535-543.

Borlongan, I., K. Tibubos, D. Yunque, A. Hurtado, and A. Critchley. 2011. Impact of AMPEP on the growth and occurrence of epiphytic Neosiphonia infestation on two varieties of commercially cultivated Kappaphycus alvarezii grown at different depths in the Philippines. J. Appl. Phycol. 23:615-621.

Chyliński, W., A. Łukaszewska, and K. Kutnik. 2007. Drought response of two bedding plants. Acta Physiol. Plant. 29: 399-406.

Craigie, J. 2011. Seaweed extract stimuli in plant science and agriculture. J. Appl. Phycol. 23:371-393.

Crouch, I.J. and J. van Staden. 1992. Effect of seaweed concentrate on the establishment and yield of greenhouse tomato plants. J. Appl. Phycol. 4:291-296.

Finnie, J.F. and J. van Staden. 1985. Effect of seaweed concentrate and applied hormones on in vitro cultured tomato roots. J. Plant Physiol. 120:215-222.

Food and Agriculture Organization of the United Nations. 2011. Yearbook of fishery and aquaculture statistics. Food and Agricultural Organisation of the United Nations, Rome. 
Gong, B., D. Wen, K. VandenLangenberg, M. Wei, F. Yang, Q. Shi, and X. Wang. 2013. Comparative effects of $\mathrm{NaCl}$ and $\mathrm{NaHCO}_{3}$ stress on photosynthetic parameters, nutrient metabolism, and the antioxidant system in tomato leaves. Sci. Hort. 157:1-12.

Hankins, S.D. and H.P. Hockey. 1990. The effect of a liquid seaweed extract from Ascophyllum nodosum (Fucales, Phaeophyta) on the two-spotted red spider mite Tetranychus urticae. Hydrobiologia 204205:555-559.

Hu, L., Z. Wang, and B. Huang. 2012. Growth and physiological recovery of kentucky bluegrass from drought stress as affected by a synthetic cytokinin 6benzylaminopurine. Crop Sci. 52:23322340 .

Hurtado, A., D. Yunque, K. Tibubos, and A. Critchley. 2009. Use of Acadian marine plant extract powder from Ascophyllum nodosum in tissue culture of Kappaphycus varieties. J. Appl. Phycol. 21:633-639.

Hurtado, A., M. Joe, R. Sanares, D. Fan, B. Prithiviraj, and A. Critchley. 2012. Investigation of the application of Acadian Marine Plant Extract Powder (AMPEP) to enhance the growth, phenolic content, free radical scavenging, and iron chelating activities of Kappaphycus Doty (Solieriaceae, Gigartinales, Rhodophyta). J. Appl. Phycol. 24:601-611.

Khan, W., D. Hiltz, A. Critchley, and B. Prithiviraj. 2011. Bioassay to detect Ascopbyllum nodosum extract-induced cytokinin-like activity in Arabidopsis thaliana. J. Appl. Phycol. 23:409-414.

Khan, W., U.P. Rayirath, S. Subramanian, M.N. Jithesh, P. Rayorath, D.M. Hodges, A.T. Critchley, J.S. Craigie, J. Norrie, and B. Prithiviraj. 2009. Seaweed extracts as bio-stimulants of plant growth and development. J. Plant Growth Regul. 28:386-399.

Krause, G.H. 1988. Photoinhibition of photosynthesis. An evaluation of damaging and protective mechanisms. Physiol. Plant. 74:566-574.

MacKinnon, S., D. Hiltz, R. Ugarte, and C. Craft. 2010. Improved methods of analysis for betaines in Ascophyllum nodosum and its commercial seaweed extracts. J. Appl. Phycol. 22:489-494.

Mishra, K.B., R. Iannacone, A. Petrozza, A. Mishra, N. Armentano, G. La Vecchia, M. Trtílek, F. Cellini, and L. Nedbal. 2012. Engineered drought tolerance in tomato plants is reflected in chlorophyll fluorescence emission. Plant Sci. 182:79-86.

Ozenc, D.B. 2008. Growth and transpiration of tomato seedlings grown in hazelnut husk compost under water-deficit stress. Compost Sci. Util. 16:125-131.

Passam, H. 2008. The fruiting species of the Solanaceae. European J. Plant Sci. Biotechnol. 2:1-2.

Rayirath, P., B. Benkel, D.M. Hodges, P. Allan-Wojtas, S. MacKinnon, A. Critchley, and B. Prithiviraj. 2009. Lipophilic components of the brown seaweed, Ascophyllum nodosum, enhance freezing tolerance in Arabidopsis thaliana. Planta 230:135-147.

Rayorath, P., M. Jithesh, A. Farid, W. Khan, R. Palanisamy, S. Hankins, A. Critchley, and B. Prithiviraj. 2008a. Rapid bioassays to evaluate the plant growth promoting activity of Ascophyllum nodosum (L.) Le Jol. using a model plant, Arabidopsis thaliana (L.). Heynh. J. Appl. Phycol. 20:423-429.

Rayorath, P., W. Khan, R. Palanisamy, S. MacKinnon, R. Stefanova, S. Hankins, A. Critchley, and B. Prithiviraj. 2008b. Extracts of the brown seaweed Ascophyllum nodosum induce gibberellic acid $\left(\mathrm{GA}_{3}\right)$ independent amylase activity in barley. J. Plant Growth Regul. 27:370-379.

Sánchez-Rodríguez, E., R. Leyva, C. Constán-Aguilar, L. Romero, and J.M. Ruiz. 2012. Grafting under water stress in tomato cherry: Improving the fruit yield and quality. Ann. Appl. Biol. 161:302-312.
Spann, T.M. and H.A. Little. 2011. Applications of a commercial extract of the brown seaweed Ascophyllum nodosum increases drought tolerance in containergrown 'Hamlin' sweet orange nursery trees. HortScience 46:577-582.

Topcu, S., C. Kirda, Y. Dasgan, H. Kaman, M. Cetin, A. Yazici, and M.A. Bacon. 2007. Yield response and Nfertiliser recovery of tomato grown under deficit irrigation. Eur. J. Agron. 1:64-70.

Ugarte, R., G. Sharp, and B. Moore. 2006. Changes in the brown seaweed Ascophyllum nodosum (L.) Le Jol. plant morphology and biomass produced by cutter rake harvests in southern New Brunswick, Canada. J. Appl. Phycol. 18:351-359.

U.S. Department of Agriculture. 2014. Floriculture crops 2013 summary. U.S. Dept. Agr., Natl. Agr. Stat. Serv., Washington, DC.

Wally, O.S.D., A.T. Critchley, D. Hiltz, J.S. Craigie, X. Han, L.I. Zaharia, S.R. Abrams, and B. Prithiviraj. 2013. Regulation of phytohormone biosynthesis and accumulation in Arabidopsis following treatment with commercial extract from the marine macroalga Ascopbyllum nodosum. J. Plant Growth Regul. 32:324-339.

Whapham, C.A., G. Blunden, T. Jenkins, and S.D. Hankins. 1993. Significance of betaines in the increased chlorophyll content of plants treated with seaweed extract. J. Appl. Phycol. 5:231-234.

Wright, R.D. 1986. The pour-through nutrient extraction procedure. HortScience 21:227-229.

Zhang, X. and E.H. Ervin. 2004. Cytokinincontaining seaweed and humic acid extracts associated with creeping bentgrass leaf cytokinins and drought resistance. Crop Sci. 44:1737-1745. 